\title{
A Model of Cultural Survival of Sundanese Ethnic Community
}

\author{
A. Hufad, J. S.Ardiwinata, Purnomo \\ Department of Non formal Education, Universitas Pendidikan Indonesia \\ Bandung, INDONESIA \\ achmadhufad@upi.edu
}

\begin{abstract}
Education process is engrossed with cultural processes as part of enculturation and socialization. Ethnic communities have their own unique patterns, ways, and characteristics in sustaining and developing their cultures. This research was conducted in the Ethnic Community of Kampung Cireundeu, Cimahi City, West Java Province, aiming to reveal a model of cultural survival model that is appropriate to the unique local wisdom. Employing the qualitative method of ethnography, the research has constructed a model of cultural survival. It was also found that the cultural survival model is rooted in the Cireundeu community's cultural universal.
\end{abstract}

Keywords: cultural survival model, ethnic communities

\section{INTRODUCTION}

Cireundeu ethnic community situated in Cimahi City, West Java Province, is considered as a community with unique characteristics in terms of its cultures and educational values. Ethnic community refers to a traditional group bonded by customs and traditions. Ethnic communities are regarded as scientific wealth that has to be continuously studied in order to improve knowledge. There are many things to learn from them, especially considering the rapid changes of times.

As an ethnic group, ethnic community has certain characteristics, such as: 1) Having members with certain requirements; 2) Having traditional houses serving certain functions 3) Having both internal and external autonomy; and 4) Having a traditional government with its own organization. The cultural values of an ethnic community certainly have a particular pattern or model. Cireundeu ethnic community is led by elders serving as custodians or caretakers of the history of the ethnic community. The majority of its people embraces and strongly uphold Sunda Wiwitan. They consistently practice their beliefs and sustain their cultures and traditions inherited from their ancestors.

Studies revealing the culture of Cireundeu people $[1,2]$ described the local's food security from economy perspective, i.e. The production, distribution, and consumption. Likewise, the studies described the people's effort to maintain the family and community's wealth. This study aims at revealing the cultural universal, i.e. the religion, organization, knowledge, live hood, technology, language and arts system, in Cireundeu community. Moreover, it seeks the pattern of cultural survival model and its supporting factors, especially their unique food security system.

\section{RESEARCH METHOD}

This research employed an ethnographic method which describes cultures, social groups or systems. The data were collected from ethnography notes, documents, observations and interviews [3]. The respondents were the elders as the caretakers of the community, the youths and members of the ethnic community.

As the aim of the research suggested, this research resulted in a narrative description of cultural survival model of Cireundeu Community constructed from its cultural universal [4].

\section{RESULT OF THE STUDY}

\section{A. Cultural Survival Model}

The cultural entity possessed by Cireundeu ethnic community is a local wisdom bearing certain values. Local wisdom is divided into two, namely the tangible one, such as cultural objects, historical and socio-cultural heritage; and the intangible one of the forms of values or meanings of a certain object. A peaceful and harmonious life, famously known in the Sundanese proverb of "silih asah, silih asih, silih asuh, tata titi" is a tradition that has been practiced by the ethnic community from one generation to the next.

An established tradition is called traditium, which is transmitted from one generation to the next. One of the examples of the community's tradition is the daily consumption of Rasi (staple food made of cassava) and its products, such as cookies and crackers. This enculturation produces varied food products that are famous both locally and internationally.

The shift from rice into Russia among the members of Cireundeu ethnic community was begun approximately in 1918 , pioneered by the respected members of the community. For the pioneering of this new staple food, the government through its district officer in Cimahi awarded the respected members with the title of "pahlawan Pangan" (food hero) in 1964.

The ethnic community strongly upholds its traditions. The members have the principle of "Ngindung Ka Waktu, Mibapak Ka Jaman", where "Ngindung Ka Waktu" means that as an ethnic community it has its own ways, characteristics, and beliefs. Meanwhile, "Mibapak $\mathrm{Ka}$ Jaman" means Cireundeu ethnic community is not isolated from the changes of times. In addition, Cireundeu ethnic community is guided by the life principle of " $\mathrm{Teu}$ Nyawah Asal Boga Pare, Teu Boga Pare Asal Boga Beas, Teu Boga Beas Asal Bisa Nyangu, Teu Nyangu Asal Dahar, Teu Dahar Asal Kuat", meaning that it does not matter if they have no rice field as long as they have the 
rice; it does not matter if they cannot cook some rice, as long as they can eat; and it does not matter if they have nothing to eat, as long as they are strong.

\section{B. Cultural Universal}

The cultural system of Cireundeu ethnic community is Sunda Wiwitan, popularized by Pangeran Madrais (Cigugur) since 1918. Until today, the life philosophy of Cireundeu ethnic community has not experienced significant changes. The members still uphold the moral teachings that have been embodied in the ancestral traditions. The ritual of satu Sura (the first day of Sura-a month in the traditional calendar), routinely held since a long time ago, is one of the symbols of the philosophy. The ceremony of "suraan" signifies that human beings live side by side with other beings, either with the environment, plants, animals, wind, ocean, mountain, soil, water, fire, wood, or sky. Therefore, human beings must know themselves and know what they feel in order to learn to feel what others and other beings feel.

Meanwhile, in terms of social system, Cireundeu ethnic community is led by sesepuh (equivalent to an elder, the gatekeeper of the ethnic community), assisted by pangampih (serving as a provider of information, language, and symbol), panitren (taking care of social relationship), and Nonoman (the youths of the ethnic community).

In terms of knowledge system in Cireundeu community, education is introduced early in the family. For instance, the head of the family continuously cultivates understanding and knowledge of the family members by introducing rasi to the children as the staple food and introducing ways to plant cassava, select the seeds, and process cassava into rice.

With regard to language system, the language used by Cireundeu ethnic community is Sundanese language. Sundanese is used orally and in writing. Indonesian is also employed by the Cireundeu people, ultimately when they converse with visitors who do not understand Sundanese.

Regarding art system, many of the art forms in Cireundeu ethnic community are managed by the nonoman (youths). Some forms of art developed are pencaksilat, karinding, degung, ngawih, and wood carving. Each nonoman studies art since he or she is young, and the elderly go as far as inviting teachers from other kampung adat (ethnic villages), such as Kuningan, to teach various forms of art.

As regards livelihood, the majority of Cireundeu ethnic community members are farmers. In addition to farming, many of them keep livestock, such as chicken, cow, and sheep. It is recorded that there are a number of 380 and 100 sheep and chicken, respectively. The community makes use of cassava peels and leaves for animal feed. In addition, the women spend their time with home industry activities, managed by business groups, producing various foods made of cassava besides rasi.

In terms of life equipment and technology, since 1918, the ethnic community of Cireundeu has maintained the ancestral traditions of choosing the staple food made of cassava. The tradition is maintained from one generation to the next. Cassava is processed in such a way that it resembles rice and appropriate to be consumed with other side dishes. The ethnic community names this staple food "sangueun", but it is now more commonly termed "rasi" (Beras Singkong, or cassava rice)". The processed food is able to improve the community's economy. This is so because cassava is not only processed into staple food, but also cake and other kinds of snack.

\section{DISCUSSION}

Geographically, the Cireundeu ethnic community is situated in Cimahi city, however the villagers' way of life is highly appreciated and practiced. The efforts made by the elderly of Cireundeu ethnic community in sustaining its culture are in the forms of advice or education, access, and control. The social, economic, and demographic conditions are the potential assets from which the community can take many benefits. The life principles cultivated among the people are the cultural values that they always uphold strongly. Ethnic environmental education is a knowledge system important to strengthen culture [5].

The success of the ethnic community in sustaining its ancestral culture lies in the elderly's attitude, where they regard culture as a mandate to be maintained and passed on from one generation to the next. Furthermore, based on the life principles upheld by the members of Cireundeu ethnic community, it is found that the people are open to the changes of times without sacrificing their own culture. Indeed, in certain condition, whether we realize it or not, we serve as "leader", where we do not only act as part of the culture, but oftentimes we create new elements to the culture; the creation of new culture, its modeling and consolidation reflects the interdependency between culture and leadership [8].

One of the successful attempts in sustaining the culture is food security that has been maintained since 1918. Cireundeu ethnic community takes advantage of cassava processed to be the substitute of rice and into other snacks or cakes. The food crisis currently experienced is not a great problem for Cireundeu community. The community even makes national and international reference for the study of the values of food security

Food security is, in fact, a form of local wisdom. This statement is based on the following arguments: 1) cassava rice is consumed by the whole members of Cireundeu ethnic community, including those outside the community, 2) the people are used to consuming cassava rice since it is introduced to them when they are really young; 3) cassava rice is the original food product of Cireundeu ethnic community, established through habituation, extension among primary family members, and interaction with other community members or environment.

The cultural survival of Cireundeu community is made possible by several actors, taking certain roles and involvement in the traditional life. The roles are varied, fulfilled by elderly (panitren), small interest groups (farmer and home industry groups), youths (initiating actors), organization (community's collective action/shared activity), and external actors (training and extension programs). Tolerance among the members is especially conspicuous during a food distribution at a certain event. 
The participation of Cireundeu ethnic community is an important component in the development of community autonomy and empowerment (9). (9) Further explains that empowerment and participation are potential strategies in an attempt of accelerating economic, social, and cultural transformations. These transformations will eventually create people-centered development. The participation and leadership of the traditional elders can be, among others, in the forms of cultural programs, land rights, traditional education, philosophical education, and the mechanisms of the teaching and learning of traditional culture.

Indeed, ethnic community tends to have the elderly as community's role models because most elders are native people and those who know the origins and cultures of the community. The elders made as role models believe in what is called Sunda Wiwitan.

Another reason the community members consume rasi is because of their belief. Centered in KuninganCirebon, this belief obliges its followers to consume nonrice food [2].

Finally, the model of cultural survival constructed by the researchers is based on the ethnographic analysis of the ethnic community in Cireundeu, which can be seen in detail in figure 1:

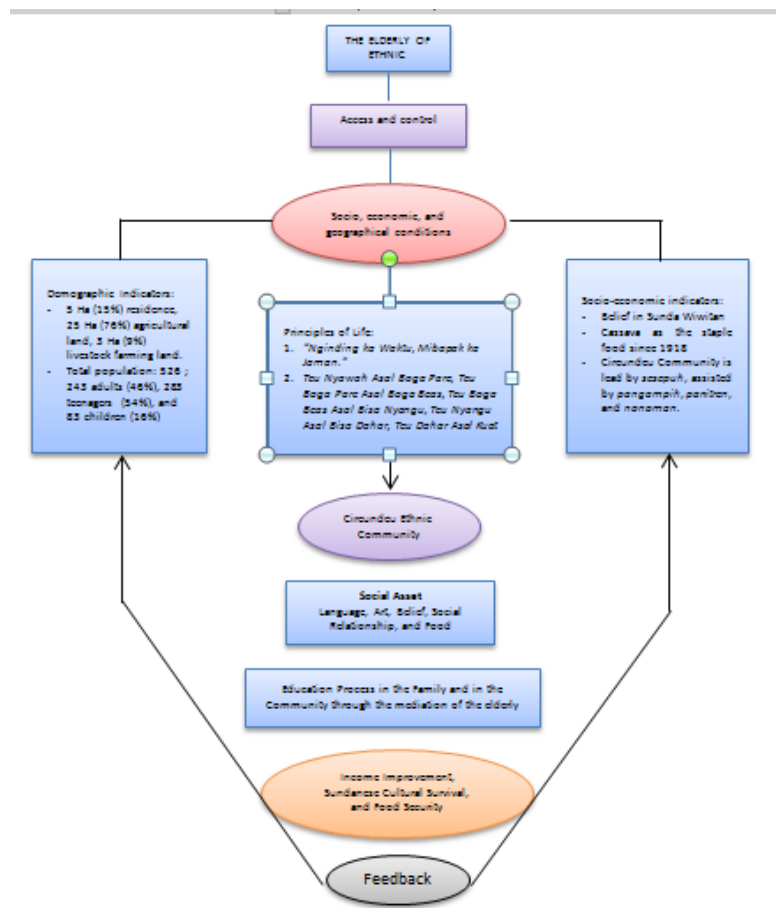

Fig. 1. A Model of Cireundeu Community Cultural Survival

\section{CONCLUSIONS}

The research described the characteristics of an ethnic community in general, namely having unique characteristics of social life. In relation to ethics and culture, the characteristics of the ethnic community under study are: humble, upholding the prevailing norms, having strong kinship, straightforward, respectful, democratic and religious, keeping promises, courteous. These are the common characteristics of rural communities. It is also found that socialization and acculturation have taken place in the ethnic community.
The model of ethnic community's cultural survival has been jointly developed with other community members. Indeed, unity in the fulfillment of duties and functions and the cultural-philosophical values are some of the efforts of sustaining the culture. The peculiar values are part of the local wisdom of Sundanese communities.

The research still has some room for improvement, such as the mapping of the cultural system of the ethnic community potential for tourism objects. Thus, future researchers are recommended to further study the same topic in a multidisciplinary context in order to gain a holistic description of the aspects potential for Edutourism.

\section{ACKNOWLEDGEMENT}

We would like to express our deepest gratitude to LPPM UPI (Institute of Research and Community Service of Indonesia University of Education) for the research grant. We would like to also appreciate Abah Asep as the adat figure who has helped the research from the beginning till its completion.

\section{REFERENCES}

[1] Amir Fadhilah. (2014). "Budaya Pangan Anak Singkong dalam Himpitan Modernisasi Pangan”. Journal Al-Turas Vol. XX No1 January 2014, pp 11-23.

[2] Qoriah Saleha. (2005). "Kajian Pola dan Kebiasaan Makan Masyarakat Cireundeu di Kelurahan Leuwigajah Kec. Cimahi Kab.Bandung". Journal EPP. Vol.2.No1.2005, pp 22-28.

[3] Atkinsinon, P \& Hammersley, M (1994). Ethnography and Participant Observation in Norman Denzin and Yvona Lincoln (Eds.), Handbook of Qualitative Research. Thousand Oaks: Sage, pp.249-261.

[4] Kluckhohn, C. (1953). Universal Categories of Culture. New York: McGraw Hill.

[5] Leanne Simpson. (2002). "Indigenous environmental education for cultural survival". Canadian Journal of environmental education. Spring 2002.

[6] Stephanie Rotarangi \& Darryn Russell. (2010). "SocialEcological resilience thinking: can indigenous culture guide environmental management?". Journal of the royal society of New Zealand. ISSN: 0303-6758 (Print) 11758899(Online). Published online 22 Feb. 2010.

[7] Anthony Bebbington et al. (2004). Vilage politics, culture and community-driven development insights form Indonesia. Journal Citation Reports Thomson Reuters, 2015). July 2004; vol 4, 3:pp.188-205.

[8] John Wiley and Sons. (2009). "Corporate culture survival guide”. Published by Jossey-Bass A Wiley Imprint 989 Market Street, San Francisco, CA 94103-1741.

[9] Victoria A.Beard and Aniruddha Dasgupta. "Collective Action and Community - driven Development in Rural and Urban Indonesia". International Journal for Urban Studies. August 2006; vol.43,9:pp 1451-1468. 